\title{
FRANZ TERMER
}

\section{Deutsche und}

nordamerikanische

\section{Auslandsforschung}

in den

ibero-amerikanischen

\section{Ländern}

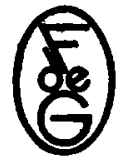

Friederichsen, de Gruyter \& Co. m. b. H., Hamburg 
